\title{
HUBUNGAN ANTARA POLA TIDUR DAN KEBIASAAN MAKAN JUNK FOOD DENGAN KEJADIAN OBESITAS PADA MAHASISWA UNIVERSITAS MALAHAYATI TAHUN 2019
}

\author{
Tanti Kristiana', Dessy Hermawan2 $2^{2}$, Upik Febriani ${ }^{3)}$, Achmad Farich ${ }^{4)}$ \\ ${ }^{1}$ Mahasiswa Program Studi Kedokteran FK Universitas Malahayati, Bandar Lampung \\ ${ }^{2}$ Dosen Program Studi Keperawatan FK Universitas Malahayati, Bandar Lampung \\ ${ }^{34}$ Dosen Program Studi Kedokteran FK Universitas Malahayati, Bandar Lampung \\ Email:Tantiskristiana04@gmail.com
}

Submitted : 02-04-2020, Reviewer: 06-04-2020, Accepted: 08-04-2020

\begin{abstract}
Obesity is a serious illness that can cause emotional and social problems. The things that cause obesity include sleep patterns, and also patterns of consumption, including consumption of junk food among teenagers.This study aimed to determine the relationship of sleep patterns and Junk food eating habits with the incidence of obesity in students at Malahayati University in 2019. The type of research used was observational quantitative research with a case control approach. The sample in this study is the medical students of the University of Malahayati Bandar Lampung in 2017 consisting of 30 people who are not obese and 30 people who are obese. Data obtained through filling questionnaires and microtoise scales. The data analysis technique to test the hypothesis is the chi square statistical test. From the results of the study showed the frequency of sleep patterns with the most obesity events in the less category (43.3\%), the frequency of junk food eating habits with the most obesity events in the frequent and always categories (38.4\%), there was a significant relationship between sleep patterns and the incidence of obesity with a $p$ value of $0,000(<\alpha 0.05)$ and there is a significant relationship between junk food eating habits with the incidence of obesity with a $p$ value of $0,000(<\alpha 0.05)$. Students with obesity consume junk food more often and obese students also have less sleep patterns than non obese students.
\end{abstract}

Keywords: Obesity, Junk food, Sleep Pattern

\begin{abstract}
Abstrak
Obesitas adalah suatu penyakit serius yang dapat mengakibatkan masalah emosional dan sosial. Hal-hal yang menyebabkan terjadinya obesitas antara lain yaitu pola tidur, dan juga pola konsumsi, termasuk diantaranya konsumsi junk food di kalangan remaja. Penelitian ini ditujukan untuk mengetahui hubungan pola tidur dan kebiasaan makan Junk food dengan kejadian obesitas pada mahasiswa Universitas Malahayati tahun 2019. Jenis penelitian yang digunakan adalah penelitian kuantitatif observasional dengan pendekatan case control. Sampel dalam penelitian ini yaitu mahasiswa kedokteran Universitas Malahayati Bandar Lampung angkatan 2017 terdiri dari 30 orang tidak obesitas dan 30 orang yang obesitas. Data diperoleh melalui pengisian kueioner dan timbangan microtoise. Teknik analisis data untuk menguji hipotesis yaitu uji statistis chi square. Dari hasil penelitian menunjukkan frekuensi pola tidur dengan kejadian obesitas paling banyak pada kategori kurang (43,3\%), frekuensi kebiasaan makan junk food dengan kejadian obesitas paling banyak pada kategori sering dan selalu $(38,4 \%)$, terdapat hubungan yang bermakna antara pola tidur dan kejadian obesitas denga $p$ value $0,000(<\alpha 0,05)$ dan terdapat hubungan yang bermakna antara kebiasaan makan junk food dengan kejadian obesitas dengan $p$ value $0,000(<\alpha 0,05)$. Mahasiswa dengan obesitas lebih sering mengkonsumsi junkfood dan mahasiwa yang obesitas juga memiliki pola tidur yang kurang daripada mahasiwa yang tidak obesitas.
\end{abstract}

Kata kunci : Obesitas, Junk food, Pola Tidur 


\section{PENDAHULUAN}

Obesitas adalah suatu penyakit serius yang dapat mengakibatkan masalah emosional dan sosial. Seseorang dikatakan overweight bila berat badannya $10 \%$ sampai dengan $20 \%$ berat badan normal, sedangkan seseorang disebut obesitas apabila kelebihan berat badan mencapai lebih $20 \%$ dari berat normal (Arisman, 2012).

Obesitas akan sulit teratasi terlebih bila sudah terjadi sejak pada masa usia remaja. Peningkatan berat badan pada masa ini akan menyebabkan peningkatan jumlah sel lemak. Sekali sel lemak ini berbentuk, maka akan sulit untuk membuangnya sehingga remaja yang mengalami obesitas akan berisiko untuk menjadi obesitas yang menetap hingga dewasa. Obesitas dipengaruhi oleh kombinasi antara faktor genetik dan lingkungan. Faktor lingkungan seperti asupan makan yang berlebihan dan aktivitas fisik yang rendah merupakan faktor penentu utama obesitas (Roemling dkk, 2012). Namun beberapa penelitian menemukan bahwa pola tidur juga memiliki kontribusi pada meningkatnya prevalensi obesitas terutama tidur yang kurang (Gradiser dkk, 2011).

Prevalensi obesitas terus meningkat di seluruh dunia dan telah menjadi epidemik global. Sedikitnya 2.8 juta orang meninggal setiap tahunnya akibat obesitas. Di dunia lebih dari 1.9 miliar orang mengalami kelebihan berat badan dan $31.6 \%$ orang mengalami obesitas. WHO memperkirakan bahwa kegemukan dan obesitas berkontribusi sebesar 5\% dalam kematian global pada 2015 (WHO, 2017).

Prevalensi overweight dan obesitas di Indonesia pada usia 18 tahun ke atas secara nasional sebesar $13.6 \%$ dan $21.8 \%$. Proporsi obesitas pada dewasa di atas 18 tahun menurut provinsi ditemukan paling banyak di provinsi Sulawesi utara sebesar $30.2 \%$ dan paling sedikit ditemukan di provinsi NTT sebesar 10.3\% (Riskesdas, 2018).

Di Provinsi Lampung terdapat $18.7 \%$ penduduk dewasa yang mengalami obesitas, sedangkan kota Bandar lampung terdapat $10.9 \%$ penduduk yang mengalami obesitas (Oemati dkk, 2013). Dari hasil pre survey yang dilakukan terhadap mahasiswa kedokteran Universitas Malahayati angkatan 2017 dari 82 orang yang dilakukan pengamatan sebanyak 16 orang yang mengalami obesitas.

Hal-hal yang menyebabkan terjadinya obesitas antara lain yaitu pola tidur, dan juga pola konsumsi, termasuk diantaranya konsumsi junk food di kalangan remaja. Junk food adalah makanan yang memiliki kandungan nutrisi yang rendah, hingga gizi yang juga sedikit. Namun junk food memiliki kadar lemak yang tinggi serta tidak baik untuk kesehatan manusia. Jenis junk food yang banyak disukai anak muda adalah makanan cepat saji yang banyak di sediakan di restoran fast food. Contoh dari makanan junk food adalah permen, minuman bersoda, coklat, keripik kentang atau snack ringan, es krim, dan masih banyak lagi (Musa, 2010).

Selain itu anak yang memiliki status sosioekonomi yang tinggi juga cenderung memiliki kebiasaan mengkonsumsi junk food. Karena peningkatan daya beli para orang tua cenderung memanjakan anak-anak mereka dengan junk food. ( Sari RW, 2008). Junk 
food yang berlimpah kalori dan lemak, namun kandungan gizi dan seratnya sangat rendah semakin disukai masyarakat modern, yang kemudian menjadi masalah nasional, yakni meningkatkan jumlah orang yang kegemukan (Made, 2012).

Tingkat pendapatan keluarga yang rendah pada penduduk permukiman padat memiliki kecenderungan bagi seseorang untuk bekerja hingga larut malam sehingga waktu tidur semakin berkurang (Jaskelainen A dkk, 2014). Tuntutan pekerjaan, penyakit gangguan tidur, ataupun sekedar gaya hidup membuat seseorang tidur larut malam (Taheri S, 2014). Waktu tidur singkat $(<6$ jam) menurut Taheri (2014) dapat mempengaruhi kerja hormon leptin dan ghrelin sehingga memicu munculnya rasa lapar yang dapat menyebabkan seseorang menjadi overeating.

\section{METODE PENELITIAN}

Jenis penelitian yang digunakan dalam penelitian ini adalah penelitian kuantitatif. Rancangan penelitian menggunakan metode analitik observasional dengan pendekatan case control. Tujuannya adalah untuk mengetahui hubungan pola tidur dan kebiasaan makan Junk Food dengan kejadian obesitas pada mahasiswa Universitas Malahayati tahun 2019Lokasi penelitian ini dilakukan di Asrama Universitas Malahayati Bandar Lampung pada bulan Januari 2020 hingga selesai.

Adapun kriteria sampel dalam penelitian ini adalah kriteria sampel yaitu mahasiswa kedokteran Universitas Malahayati Bandar Lampung angkatan 2017, tercatat masih aktif sebagai mahasiswa dan bersedia menjadi responden dalam penelitian ini.

Pada penelitian ini yang menjadi variabel dependennya adalah kejadian obesitas pada mahasiswa di Universitas Malahayati dan variabel independennya adalah pola tidur dan kebiasaan makan Junk Food.

Analisis data yang digunakan dalam penelitian ini adalah teknik analisis kuantitatif, yaitu analisis univariat dan analisis bivariat menggunakan Uji statistik Chi square. Uji satatistik Chi square yang dilakukan dalam penelitian ini dengan bantuan program komputer yaitu SPSS 24 .

\section{HASIL DAN PEMBAHASAN}

Tabel 1. Umur

\begin{tabular}{ccc}
\hline Umur & Jumlah & $\begin{array}{c}\text { Persentase } \\
(\mathbf{\%})\end{array}$ \\
\hline 19 & 5 Orang & 8,3 \\
20 & 24 Orang & 40 \\
21 & 24 Orang & 40 \\
22 & 2 Orang & 6,7 \\
23 & 1 Orang & 1,7 \\
24 & 2 Orang & 3,3 \\
\hline Total & $\mathbf{6 0}$ Orang & $\mathbf{1 0 0}$ \\
\hline
\end{tabular}

Berdasarkan tabel di atas diketahui bahwa distribusi frekuensi responden berdasarkan umur sebanyak 5 orang berumur 19 tahun (8,3\%), sebanyak 24 orang berumur 20 tahun (40\%), sebanyak 24 orang berumur 21 tahun (40\%), sebanyak 2 orang berumur 22 tahun $(6,7 \%)$, sebanyak 1 orang berumur 23 tahun $(1,7 \%)$ dan sebanyak 2 orang berumur 24 tahun $(3,3 \%)$. Sebagian besar responden berumur 20-21 tahun.

Tabel 2. Jenis Kelamin

\begin{tabular}{ccc}
\hline $\begin{array}{c}\text { Jenis } \\
\text { Kelamin }\end{array}$ & Jumlah & $\begin{array}{c}\text { Persentase } \\
(\mathbf{\%})\end{array}$ \\
\hline Laki-laki & 28 & 46,7 \\
Perempuan & 32 & 53,3 \\
\hline Total & $\mathbf{6 0}$ & $\mathbf{1 0 0}$ \\
\hline
\end{tabular}

Berdasarkan tabel di atas diketahui bahwa sebagian besar responden berjenis 
kelamin perempuan yaitu sebanyak 32 orang $(53,3 \%)$ dan responden yang berjenis kelamin laki-laki sebanyak 28 orang $(46,7 \%)$.

Tabel 3. Kejadian Obesitas

\begin{tabular}{ccc}
\hline & Kasus & Kontrol \\
\hline $\bar{x}$ & 31,73 & $22,18 \mathrm{~kg} / \mathrm{m}^{2}$ \\
& $\mathrm{~kg} / \mathrm{m}^{2}$ & \\
Min & $27 \mathrm{~kg} / \mathrm{m}^{2}$ & $19 \mathrm{~kg} / \mathrm{m}^{2}$ \\
Maks & $44 \mathrm{~kg} / \mathrm{m}^{2}$ & $24 \mathrm{~kg} / \mathrm{m}^{2}$ \\
\hline IMT & Jumlah & $\begin{array}{c}\text { Persentase } \\
(\boldsymbol{\%})\end{array}$ \\
\hline Obesitas & 30 & 50 \\
Tidak & 30 & 50 \\
Obesitas & & $\mathbf{1 0 0}$ \\
\hline Total & $\mathbf{6 0}$ &
\end{tabular}

Berdasarkan tabel di atas menunjukkan bahwa pada kelompok kasus, rata-rata IMT responden adalah $31,73 \mathrm{~kg} / \mathrm{m} 2$ dengan IMT minimum $27 \mathrm{~kg} / \mathrm{m} 2$ dan IMT maksimum $44 \mathrm{~kg} / \mathrm{m} 2$. Sementara itu, pada kelompok kontrol atau tidak obesitas, ratarata IMT adalah 22,18 kg/m2 dengan IMT minimum $19 \mathrm{~kg} / \mathrm{m} 2$ dan IMT maksimum 24 $\mathrm{kg} / \mathrm{m} 2$. Didapatkan sebanyak 30 orang dengan kejadian obesitas atau sebagai kasus $(50 \%)$ dan sebanyak 30 orang tidak obesitas atau sebagai kontrol (50\%).

Tabel 4. Pola Tidur

\begin{tabular}{ccc}
\hline $\begin{array}{c}\text { Pola } \\
\text { Tidur }\end{array}$ & Jumlah & $\begin{array}{c}\text { Persentase } \\
(\boldsymbol{\%})\end{array}$ \\
\hline Cukup & 31 & 51,7 \\
Kurang & 29 & 48,3 \\
\hline Total & $\mathbf{6 0}$ & $\mathbf{1 0 0}$ \\
\hline
\end{tabular}

Berdasarkan tabel di atas bahwa distribusi frekuensi responden berdasarkan pola tidur cukup sebanyak 31 orang $(51,7 \%)$ dan pola tidur kurang sebanyak 29 orang $(48,3 \%)$.
Tabel 5. Kebiasaan Makan Junk Food

\begin{tabular}{ccc}
\hline $\begin{array}{c}\text { Kebiasaan } \\
\text { Makan }\end{array}$ & Jumlah & $\begin{array}{c}\text { Persentase } \\
(\%)\end{array}$ \\
Junk Food & & 60 \\
\hline $\begin{array}{c}\text { Jarang dan } \\
\text { tidak Pernah } \\
\text { Selalu dan } \\
\text { Sering }\end{array}$ & 36 & 40 \\
\hline Total & $\mathbf{6 0}$ & $\mathbf{1 0 0}$ \\
\hline
\end{tabular}

Berdasarkan tabel di atas diketahui bahwa distribusi frekuensi responden berdasarkan kebiasaan makan Junk Food kategori jarang dan tidak pernah sebanyak 36 orang $(60 \%)$. Berdasarkan kebiasaan makan Junk Food kategori selalu dan sering sebanyak 24 orang (40\%).

Tabel 6. Hubungan Pola Tidur Dengan Kejadian Obesitas Pada Mahasiswa Universitas Malahayati Tahun 2019.

\begin{tabular}{|c|c|c|c|c|c|c|c|c|}
\hline \multirow[t]{2}{*}{$\begin{array}{c}\text { Pol } \\
\text { a } \\
\text { Tid } \\
\text { ur }\end{array}$} & \multicolumn{2}{|c|}{$\begin{array}{c}\text { Kasu } \\
\text { s } \\
\text { Obes } \\
\text { itas }\end{array}$} & \multicolumn{2}{|c|}{$\begin{array}{c}\text { Kont } \\
\text { rol } \\
\text { Tida } \\
\text { k } \\
\text { Obes } \\
\text { itas } \\
\end{array}$} & \multicolumn{2}{|c|}{ Total } & \multirow[t]{2}{*}{$\begin{array}{c}\text { p- } \\
v a \\
l u \\
e\end{array}$} & \multirow[t]{2}{*}{$\begin{array}{c}\text { OR } \\
(\text { CI9 } \\
5 \%)\end{array}$} \\
\hline & $\mathbf{N}$ & $\%$ & $\mathbf{N}$ & $\%$ & $\mathbf{N}$ & $\%$ & & \\
\hline $\begin{array}{l}\text { Kur } \\
\text { ang }\end{array}$ & $\begin{array}{l}2 \\
6\end{array}$ & $\begin{array}{c}4 \\
3, \\
3 \\
\%\end{array}$ & 3 & $\begin{array}{l}5 \\
\%\end{array}$ & $\begin{array}{l}2 \\
9\end{array}$ & $\begin{array}{c}8 \\
8, \\
3 \\
\%\end{array}$ & $\begin{array}{c}0, \\
00 \\
0\end{array}$ & $\begin{array}{c}58.5 \\
00 \\
(11 . \\
919- \\
287 . \\
120)\end{array}$ \\
\hline $\begin{array}{l}\mathrm{Cu} \\
\text { kup }\end{array}$ & 4 & $\begin{array}{l}6, \\
7 \\
\%\end{array}$ & $\begin{array}{l}2 \\
7\end{array}$ & $\begin{array}{l}4 \\
5 \\
\%\end{array}$ & $\begin{array}{l}3 \\
1\end{array}$ & $\begin{array}{l}1 \\
1, \\
7 \\
\%\end{array}$ & & \\
\hline $\begin{array}{l}\text { Tot } \\
\text { al }\end{array}$ & $\begin{array}{l}3 \\
\mathbf{0}\end{array}$ & $\begin{array}{l}5 \\
0 \\
\%\end{array}$ & $\begin{array}{l}3 \\
\mathbf{0}\end{array}$ & $\begin{array}{l}5 \\
0 \\
\%\end{array}$ & $\begin{array}{l}6 \\
0\end{array}$ & $\begin{array}{l}1 \\
0 \\
0 \\
\%\end{array}$ & & \\
\hline
\end{tabular}


Berdasarkan hasil analisis bivariat dapat diketahui bahwa responden dengan pola tidur kurang yang mengalami kejadian obesitas sebanyak 26 orang $(43,3 \%)$ sedangkan responden dengan pola tidur kurang yang tidak mengalami kejadian sebanyak 3 orang (5\%). Sementara itu responden dengan pola tidur cukup yang mengalami kejadian obesitas sebanyak 4 orang $(6,7 \%)$ dan responden dengan pola tidur cukup yang tidak mengalami kejadian obesitas sebanyak 27 orang (45\%), Hasil uji statistik diperoleh nilai p-value 0,000 dimana kurang dari nilai kemaknaan yaitu $5 \%$ (0.05). hal tersebut menunjukkan terdapat hubungan yang bermakna antara pola tidur dengan kejadian Obesitas. Dari analisis di atas didapatkan nilai $\mathrm{OR}=$ 58.500 yang menunjukkan bahwa mahasiswa yang pola tidurnya kurang berisiko 58,5 kali untuk mengalami Obesitas.

Tabel 7. Hubungan Kebiasaan Makan Junk Food Dengan Kejadian Obesitas Pada Mahasiswa Universitas Malahayati Tahun 2019.

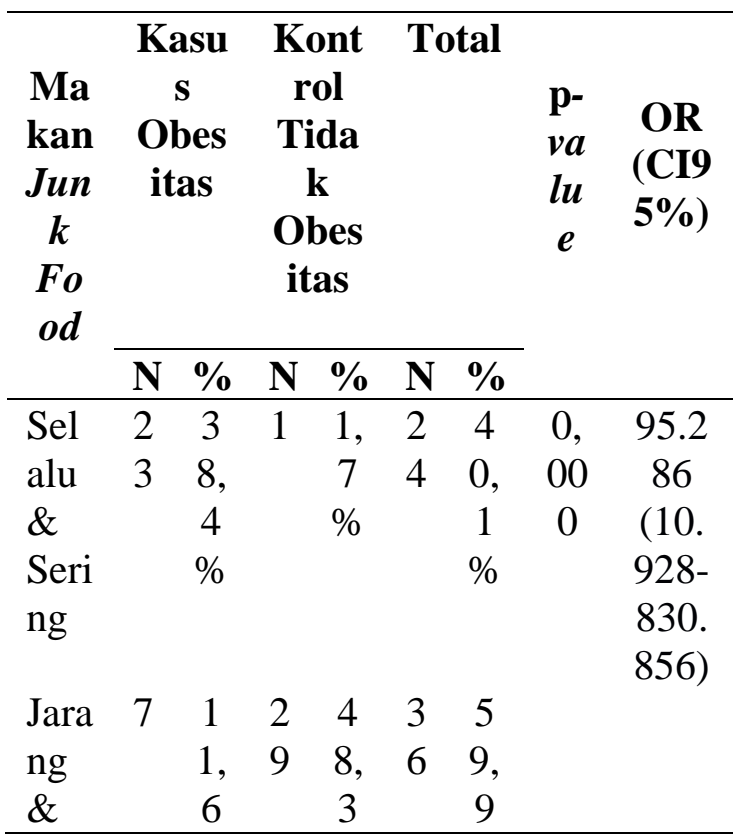

\begin{tabular}{lllllll}
$\begin{array}{l}\text { Tid } \\
\text { ak }\end{array}$ & $\%$ & & $\%$ & & $\%$ \\
Per & & & & & & \\
nah & & & & & & \\
\hline Tot & $\mathbf{3}$ & $\mathbf{5}$ & $\mathbf{3}$ & $\mathbf{5}$ & $\mathbf{6}$ & $\mathbf{1}$ \\
al & $\mathbf{0}$ & $\mathbf{0}$ & $\mathbf{0}$ & $\mathbf{0}$ & $\mathbf{0}$ & $\mathbf{0}$ \\
& & $\boldsymbol{\%}$ & & $\mathbf{\%}$ & & $\mathbf{0}$ \\
& & & & & & $\mathbf{\%}$ \\
\hline
\end{tabular}

Berdasarkan hasil analisis bivariat dapat diketahui bahwa responden dengan kebiasaan makan junk food kategori selalu dan sering sebanyak 23 orang $(38,4 \%)$ yang mengalami kejadian obesitas dan responden dengan kebiasaan makan junk food kategori selalu dan sering sebanyak 1 orang $(1,7 \%)$ yang tidak mengalami kejadian obesitas. Sementara itu, responden dengan kebiasaan makan junk food kategori jarang dan tidak pernah didapatkan sebanyak 7 orang $(11,6 \%)$ yang mengalami kejadian obesitas dan responden dengan kebiasaan makan junk food kategori jarang dan tidak pernah didapatkan sebanyak 29 orang $(48,3 \%)$ yang tidak mengalami kejadian obesitas. Hasil uji statistik diperoleh nilai p-value 0,000 dimana kurang dari nilai kemaknaan yaitu $5 \%$ (0.05). Hal tersebut menunjukkan terdapat hubungan yang bermakna antara kebiasaan makan junk food dengan kejadian Obesitas. Dari analisis di atas didapatkan nilai $\mathrm{OR}=95.286$ yang menunjukkan bahwa mahasiswa yang pola tidurnya kurang berisiko 95,2 kali untuk mengalami Obesitas.

Berdasarkan hasil uji statistik chi square hubungan antara pola tidur dengan kejadian obesitas diperoleh nilai $\mathrm{p}$ adalah 0,000 . Karena $\mathrm{p}<0,05$ maka secara statistik terdapat hubungan yang bermakna antara pola tidur dengan kejadian obesitas pada mahasiswa kedokteran Universitas Malahayati Bandar Lampung angkatan 2017. Diketahui bahwa responden dengan pola tidur cukup yang mengalami kejadian obesitas sebanyak 4 orang $(6,7 \%)$. 
Responden dengan pola tidur cukup yang tidak mengalami kejadian obesitas sebanyak 27 orang $(45 \%)$, responden dengan pola tidur kurang yang mengalami kejadian obesitas sebanyak 26 orang $(43,3 \%)$ sedangkan responden dengan pola tidur kurang yang tidak mengalami kejadian sebanyak 3 orang $(5 \%)$.

Pada penelitian ini terdapat responden dengan pola tidur cukup yang mengalami kejadian obesitas sebanyak 4 orang $(6,7 \%)$ dikarenakan obesitas dapat dipengaruhi berbagai faktor lainnya, seperti faktor aktifitas fisik yaitu seseorang dengan aktivitas fisik yang kurang, faktor lingkungan yaitu perilaku atau pola gaya hidup seseorang apa yang dimakan dan beberapa kali makan dan faktor psikososial yaitu apa yang ada dalam pikiran seseorang dapat mempengaruhi kebiasaan makannya (Proverawati, 2010). Jadi, bukan hanya disebabkan oleh faktor pola tidur saja.

Penelitian ini sejalan dengan penelitian yang dilakukan oleh marfuah (2013) dengan judul kualitas tidur berhubungan dengan obesitas pada anak sekolah dasar di Yogyakarta. Hasil penelitian tersebut menunjukkan kualitas tidur yang buruk 2,28 kali lebih tinggi menyebabkan obesitas dengan $\mathrm{p}$ - value 0,008. Hal ini disebabkan karena kualitas tidur yang buruk dapat mengakibatkan perasaan kelelahan pada saat bangun tidur. Kelelahan ini dapat menyebabkan penurunan aktifitas fisik yaitu kurang nya partisipasi dalam berolahraga dan terjadi peningkatan sedentary lifestyle seperti menonton tv.

Berkurangnya jam tidur selama 1 jam juga akan meningkatkan rasa lapar dan menyebabkan peningkatan berat badan sebesar $0,7 \mathrm{~kg}$. Kurang tidur menyebabkan perubahan masa lemak tubuh dan peningkatan berat badan (Logue \& Scott, 2015).
Hasil penelitian di atas sejalan dengan penelitiian Indrayani (2017) yang menunjukkan bahwa terdapat terdapat hubungan antara pola makan junk food, aktivitas fisik dan durasi tidur dengan kejadian obesitas pada pegawai di Universitas Pembangunan Nasional "Veteran" Jakarta tahun 2017. Hubungan yang bermakna antara durasi tidur $(p=0,001)$, catatan tidur 6 hari $(p=0,019)$, aktivitas fisik $(p=0,044)$ dan pola makan junk food $(p=0,006)$ dengan kejadian obesitas pada pegawai di Universitas Pembangunan Nasional "Veteran" Jakarta.

Penyebab paling mendasar terjadinya obesitas adalah ketidakseimbangan energi yang masuk dan energi yang keluar (Brown, 2005). Hasil dari penelitian Ramadhaniah (2014) melaporkan bahwa sebesar 62,22\% tenaga kesehatan di puskesmas Aceh yang obesitas memiliki durasi tidur dibandingkan dengan tenaga kesehatan di puskesmas Aceh yang tidak obesitas $(36,78 \%)$ dengan nilai $\mathrm{p}$ yaitu 0,001. Hal tersebut membuktikan bahwa terdapat perbedaan signifikan antara durasi tidur dengan obesitas. Orang obesitas biasanya memiliki waktu tidur yang kurang atau biasa disebut dengan insomnia. Hal ini disebabkan karena orang yang obesitas biasanya memiliki aktivitas fisik yang kurang pada siang hari sehingga mengakibatkan insomnia pada malam hari (Nuraliyah, 2014). Penelitian lain membuktikan bahwa durasi tidur $(<8$ jam $)$ berhubungan dengan peningkatan resiko kejadian obesitas pada dewasa ( Beccuti dan Pennain, 2011).

Berkurangnya jam tidur selama 1 jam juga akan meningkatkan rasa lapar dan menyebabkan peningkatan berat badan sebesar $0,7 \mathrm{~kg}$. Kurang tidur menyebabkan perubahan masa lemak tubuh dan peningkatan berat badan (Logue \& Scott, 2015).

Menurut peneliti bahwa hal tersebut dapat dimaknai dengan masih banyaknya 
responden yang memiliki pola tidur tidak teratur sehingga dapat memicu rasa lapar pada malam hari sekaligus mengganggu waktu istirahat tubuh beserta organ pencernaan dan dapat meningkatkan kejadian obesitas. Pada responden yaitu mahasiswa kedokteran universitas malahayati 2017 dimana mahasiswa tersebutt sedang menempuh semester 6-7. Pada semester ini sedang mengalami masa kesibukan yang padat dikampus. Jam kuliah semester ini terkadang mendadak ada jadwal dan ditambah lagi oleh banyaknya tugas tutorial, skill lab dan praktikum. Sehingga mahasiswa sering begadang pada malam hari dan dapat memicu rasa lapar sekaligus menganggu waktu istirahat tubuh beserta organ pencernaan dan dapat meningkatkan kejadian obesitas.

Berdasarkan hasil uji statistik chi square hubungan antara kebiasaan makan junk food dengan kejadian obesitas diperoleh nilai $\mathrm{p}$ adalah 0,000 . Karena $\mathrm{p}$ $<0,05$ maka secara statistik terdapat hubungan yang bermakna antara kebiasaan makan junk food dengan kejadian obesitas pada mahasiswa kedokteran Universitas Malahayati Bandar Lampung angkatan 2017. Diketahui bahwa responden dengan kebiasaan makan junk food kategori jarang dan tidak pernah didapatkan sebanyak 7 orang $(11,6 \%)$ yang mengalami kejadian obesitas dan responden dengan kebiasaan makan junk food kategori jarang dan tidak pernah didapatkan sebanyak 29 orang (48,3\%) yang tidak mengalami kejadian obesitas. Sementara itu, responden dengan kebiasaan makan junk food kategori selalu dan sering sebanyak 23 orang $(38,4 \%)$ yang mengalami kejadian obesitas dan responden dengan kebiasaan makan junk food kategori selalu dan sering sebanyak 1 orang $(1,7 \%)$ yang tidak mengalami kejadian obesitas.

Pada penelitian ini masih ditemukan responden yang mengalami obesitas namun memiliki kebiasaan makan junk food kategori jarang dan tidak pernah. Obesitas sendiri dipengaruhi oleh kombinasi faktor genetik dan faktor lingkungan. Faktor genetik, dalam hal ini yaitu parental fatness, memiliki kemungkinan berperan dalam timbulnya obesitas seperti yang diungkapkan oleh penelitian Suryaputra \& Nadhiroh (2012). Sedangkan faktor lingkungan yang berpengaruh meliputi asupan makan yang berlebih (junk food), aktivitas fisik yang rendah, serta gaya hidup yang tidak sehat. Jadi, kebiasaan makan junk food bukan merupakan faktor yang berdiri sendiri akan timbulnya obesitas pada remaja. Hasil penelitian di atas sesuai dengan penelitian yang dilakukan oleh Tambunan yang mendapatkan hasil bahwa kelompok obesitas lebih sering mengkonsumsi junkfood dari pada kelompok yang tidak obesitas. Berdasarkan hasil analisis statistik dengan analisis chi-square dalam penelitiannya diperoleh nilai $\mathrm{p}$ dalah 0,003 $(\mathrm{p}<0,05)$ yang menyatakan adanya hubungan konsumsi makanan junkfood dengan obesitas pada siswa kelas V dan VI SD Shaffiyatul Amaliyyah Medan. Beberapa penelitian yang pernah dilakukan sebelumnya yaitu oleh Anugrah 2014 yang meneliti pengaruh mengkonsumsi junkfood terhadap obesitas pada anak sekolah di SD meranti mengemukakan bahwa anak yang sering mengkonsumsi junkfood $(>3 \mathrm{x}$ per minggu).

Frekuensi makan dan jenis makanan juga sangat berpengaruh terhadap terjadinya obesitas karena kemampuan tubuh untuk menyimpan makanan yang berupa karohidrat dan protein secara terbatas. Jika mengkonsumsi Makanan junkfood yang mempunyai nilai indeks glikemik yang tinggi, sebagian yang mengandung karbohidrat akan disimpan sebagai glikogen dan sisanya menjadi lemak, protein akan dibentuk sebagai protein tubuh dan sisanya adalah lemak, sumber energi yang digunakan berasal dari glikogen (simpanan 
karbohidrat) sehingga lemak yang tertimbun tidak terpakai. Apabila hal ini terulang terus menerus, timbunan lemak akan semakin menumpuk, menjadi abnormal dan menyebabkan obesitas.

Pola makan dan aktivitas fisik merupakan salah satu faktor penentu terjadinya kejadian obesitas. Menurut Budiyanto (2010) apabila jumlah asupan makanan yang masuk lebih banyak dibandingkan jumlah kalori yang dikeluarkan dari aktivitas fisik sehari-hari maka dapat memicu terjadinya obesitas. Hasil dari penelitian Kurniawati (2016) melaporkan bahwa terdapat perbedaan yang signifikan antara aktivitas fisik dengan obesitas pada polisi yang memiliki aktivitas fisik sedang $(92,9 \%)$ dan tinggi $(7,1)$ di Kepolisian Resort Kota Banjarmasin. Kurangnya aktivitas fisik menyebabkan banyak energi yang tersimpan sebagai lemak yang berakibat terjadinya kegemukan (Wijayanti, 2013).

Hasil penelitian ini sejalan dengan penelitian yang dilakukan oleh Siregar (2013) dengan judul "Hubungan Pola Makan dengan Kejadian Overweight pada Mahasiswa di STIKES Medistra Indonesia (2013)", menunjukkan bahwa mahasiswa dengan pola makan baik paling banyak pada mahasiswa tidak overweight sebanyak 38 mahasiswa $(74,5 \%)$, dan mahasiswa dengan pola makan buruk paling banyak pada mahasiswa overweight sebanyak 44 mahasiswa $(57,1 \%)$.

Pola makan yang baik hendaknya mencukupi kebutuhan energi sehari. Selain itu, mengonsumsi junk food juga dapat menyebabkan peningkatan kegemukan atau obesitas. Penelitian dari Nadimin (2010) membuktikan bahwa sebesar $50 \%$ pegawai Dinkes Sulawesi Selatan yang obesitas memiliki pola makan junk food yang sering. Saat ini konsumsi junk food lebih cenderung meningkat di kota-kota besar. Hal ini disebabkan karena sebagian besar masyarakat di kota besar menginginkan yang serba instan seperti junk food (Nirwana, 2012).

Menurut peneliti bahwa kebiasaan makan junk food yang berlebihan dapat memicu kejadian obesitas tersebut karena mengandung tinggi kalori, tinggi gula, tinggi kolestrerol dan rendah serat serta nutrisi, bila jumlah ini terlalu banyak dalam tubuh maka akan menimbulkan banyak penyakit sehingga bila dikonsumsi berlebihan dapat menyebabkan terjadinya gizi lebih atau kegemukan (obesitas).. Makanan junk food banyak mengandung gula buatan yang tidak baik untuk kesehatan. Makanan atau minuman yang mengandung banyak gula antara lain cake,cookies dan minuman bersoda (soft drink). Di antara semua di atsa, minuman bersoda mengandung paling banyak gula. Dalam satu kaleng soft drink mengandung sedikitnya Sembilan sendok the gula. Padahal, dalam sehari tubuh kita hanya membutuhkan empat gram atau satu sendok teh saja, tidak boleh lebih. Begitu pun dengan makanan junk food yang mengandung banyak kolesterol, akan menyebabkan penumpukan lemak jahat dalam tubuh dan tidak hanya menyebabkan obesitas saja namun memicu banyak penyakit.

\section{SIMPULAN}

1. Ada hubungan yang bermakna antara pola tidur dengan kejadian obesitas pada mahasiswa Universitas Malahayati Tahun 2019 dengan nilai p sebesar 0,000. Dari analisis di atas didapatkan nilai $\mathrm{OR}=58.500$ yang menunjukkan bahwa mahasiswa yang memiliki pola tidur kurang berisiko 58.5 kali untuk mengalami kejadian obesitas.

2. Ada hubungan yang bermakna antara kebiasaan makan junk food dengan 
kejadian obesitas pada mahasiswa Universitas Malahayati Tahun 2019 dengan nilai p sebesar 0,000. Dari analisis di atas didapatkan nilai $\mathrm{OR}=$ 95.286 yang menunjukkan bahwa mahasiswa yang selalu dan sering melakukan kebiasaan makan junk food berisiko 95.2 kali untuk mengalami kejadian obesitas.

\section{REFERENSI}

Adriani, Merryana dan Bambang Wirjatmadi. 2012. Pengantar Gizi Masyarakat.Jakarta: Kencana Prenada Media Grup.

Almatsier, Sunita. 2009. Prinsip Dasar Ilmu Gizi. Jakarta: PT Gramedia Pustaka Utama

American Institute for Cancer Research.Food, Nutrition, Physical Activity, and the Prevention of Cancer: A Global Perspective. Available from http://www.aicr.org/assets/docs/pdf/re p orts/Second_Expert_Report.pdf. Diakses pada 18 Juli 2017.

Almuhanna, Monira Abdulrahman, Mohammed Alsaif, Muslim Alsaadi, Ali Almajwal. 2014. Fast Food Intake and Prevalence of Obesity in School Children in Riyadh City. Sudanese Journal of Paediatrics, Vol. 14(1): 7180

Arlinda, Sheva dan Warsiti. 2015. Hubungan Konsumsi Fast Food dengan Obesitas pada Remaja

Bahari, H. 2013. Anda Harus Tahu! Makanan-Makanan Pemicu Penyakit Kanker dan Jantung. Jogjakarta: Buku Biru.

Centers for Disease Control. 2017. How Much Sleep Do I Need? Diakses di https://www.cdc.gov.

Arisman, MB. 2014. Buku Ajar Ilmu Gizi:Obesitas, Diabetes Melitus, \&
Dislipidemia: Konsep, teori dan penanganan aplikatif. Jakarta: EGC.

Dee Pika V, Pallavi S, Subita P, Balkrishna A, Ramesh C. 2015. A Study of Select Epidemiological Factors Associated with Obesity in Women above 20 Years of Age in an Urban Slum Area. International Journal of Medical and Health Research; 1(3): 74-80.

Dasar, R.K., 2007. Laporan Hasil Riset Kesehatan Dasar (Riskesdas) Nasional 2007. Jakarta: Badan Litbangkes, Depkes RI.

Darmayana, Hizkia. 2017. Semakin Banyak Orang Indonesia Alami Obesitas. Diakses di https://www.cnnindonesia.com.

Dinas Kesehatan Probolinggo. 2018. Syarat Jajanan Sekolah. Diakses di http://dinkes.probolinggokota.go.id.

Departemen Gizi dan Kesehatan Masyarakat FKM UI. 2010. Gizi dan Kesehatan Masyarakat. Jakarta: Raja Grafindo Persada

Damopolii, W., Mayulu, N., dan Gresty, M. 2013. Hubungan Konsumsi Fast Food dengan Kejadian Obesitas pada Anak SD di Kota Manado. Ejournal keperawatan.1(1): 1-7

Farshchi HR, Taylor MA, Macdonald IA. 2005. Beneficial Metabolic Effects of Regular Meal Frequency on Dietary Thermogenesis, Insulin Sensitivity, and Fasting Lipid Profiles in Healthy Obese Women. American Journal Clinical Nutrition; 81: 16 -24.

Fauci,A. S., et al., 2009. Obesity. In : Harisson's Manual Of Medicine 17 th Edition. USA : The McGraw-Hill Companies, 939

Farida, N. 2009. Hubungan Mengkonsumsi Makanan Cepat Saji dengan Obesitas pada Remaja SMPN 85 Pondok Labu Jakarta Selatan. Skripsi. Jakarta : 
Universitas Pembangunan Nasional "Veteran" Jakarta.

Food and Agriculture Organization. 2018. Street Foods. Diakses di www.fao.org.

Gradisar, M., Gardner, G., Dohnt, H. 2011. Recent worldwide sleep patterns and problems during adolescence: A review and meta-analysis of age, region, and sleep. Sleep Medicine, 12, pp. 110-118.

Hidayat, A. Aziz Alimul. 2008. Penganar kebutuhan dasar manusia. Jakarta: Salemba Medika

Hastono, S. P. 2016. Analisis data pada bidang kesehatan. Jakarta: Raja Grafindo Persada.

Istiqomah, Sarah Nabila dan Lisiswanti Rika. 2017. Dampak Eksposur Layar Monitor terhadap Gangguan Tidur dan Tingkat Obesitas pada Anak. Medical Journal of Lampung University, Vol. 6(2): 72-77

Ivonne. 2006. Gambaran Konsumsi Makanan Jajanan terhadap Status Gizi Siswa SDN Malaka Jaya 07 Pagi Jakarta Timur. Skripsi. Depok: Gizi Kesehatan Masyarakat, FKMUniversitas Indonesia.

Kemenkes RI. Riset Kesehatan Dasar 2013. Diakses di http://www.depkes.go.id.

Koolhaas, Chantal M, Klodian Dhana, Josje D Schoufour, M Arfan Ikram, Maryam Kavousi, Oscar H Franco. 2017. Impact of Physical Activity on the Association of Overweight and Obesity with Cardiovascular Disease: The Rotterdam Study. European Journal of Preventive Cardiology, Vol. 24(9): 933-940

Li C.W., Chen I.C., Chang Y.C., Loke S.S., Wang S.H., Hsiao K.Y., 2013. W aistto-height Ratio, Waist Circumference, and Body Mass Index as Indices of Cardiometabolic Risk Among 36,642 Taiwanese Adults. Eur.J.Nutr. 52: 57-65.
Li, Lian, Shuang Zhang, Yubei Huang, Kexin Chen. 2017. Sleep Duration and Obesity in Children: A Systematic Review and Meta-Analysis of Prospective Cohort Studies. Journal of Paediatrics and Child Health, Vol. 53(4): 378-385

Lanywati, Endang. 2001. Insomnia Gangguan Sulit Tidur. Yogyakarta: Kanisius Lumbantobing. 2004. Gangguan Tidur, Jakarta : Balai Penerbit FKUI

Marfuah, Dewi, Hamam Hadi, Emy Huriyati. 2013. Durasi dan Kualitas Tidur Hubungannya dengan Obesitas pada Anak Sekolah Dasar di Kota Yogyakarta dan Kabupaten Bantul. Jurnal Gizi dan Dietetik Indonesia,Vol. 1(2): 93-101

McCall, M. W.2012. Sleep in the Eldrly: Burden, Diagnosis, and Treatment. Prim Care Companion $\mathrm{J}$ Clin Psychiatry; 6: 9-20

Mumtahanah. 2002. Gambaran Pola Konsumsi Makanan Siap Saji pada Remaja di dua Sekolah Lanjutan (SLTP) di Wilayah Jakarta Selatan. Skripsi. Depok: Gizi Kesehatan Masyarakat, FKM-Universitas Indonesia

Nurzakiah N, Echadi E, Sartika RA.2010. Faktor Risiko Obesitas pada Orang Dewasa Urban dan Rural. Jurnal Kesehatan Masyarakat Nasional; 5(1): 29-34.

Notoatmodjo, S. 2012. Metodologi Penelitian Kesehatan. Jakarta : Rineka Cipta.

Newton, Suzy, Dejana Braithwaite, Tomi F. Akinyemiju. 2017. Socioeconomic Status over the Life Course and Obesity:Systematic Review and Meta- Analysis. PLos One, Vol. 12(5):1-15.

Nugraha, Gaga Irawan. 2009. Etiologi 
dan Patofisiologi Obesitas dalam Obesitas Permasalahan dan Terapi Praktis. Jakarta: Sagung Seto

Ogden, Cynthia L, Margaret D. Carroll, Cheryl D. Fryar, Katherine M. Flegal. 2016.Prevalence of Obesity in 20112014. National Center For Health Statistic DataBrief No. 219.

Oviyanti, PN. 2010. Hubungan Antara Lingkar Pinggang dan Rasio Lingkar Pinggang Panggul dengan tekanan Darah pada Subjek Usia Dewasa. Skripsi. Universitas Negeri Surakarta. Surakarta

Popkin, BM, Adair LS, Ng SW. 2012. Now and Then: The Global Nutrition Transition: The Pandemic of Obesity in Developing Countries. Nutrition Reviews; 70(1):3-21.

Prio PA. Durasi Tidur Singkat dan Obesitas. J Majority 2015; 4(6): 5-9.

Pemerintah Kota Surabaya.2017. Profil Kelurahan Simolawang, Kecamatan Simokerto. 475/10/436.10.19/2017

Pramono, Adriyan dan Sulchan, Mohammad. 2014. Kontribusi Makanan Jajan dan Aktivitas Fisik terhadap Kejadian Obesitas pada Remaja di Kota Semarang. Jurnal Gizi Indonesia, Vol. 2(2):59-65.

Pratiwi, Azizah Ajeng dan Nindya Triska Susila. 2017. Hubungan Konsumsi Camilan dan Durasi Waktu Tidur dengan Obesitas di Permukiman Padat Kelurahan Simolawang Surabaya. Research Study, Vol. 1(3): 153-161

Riswanti Septiani .2017. Pola Konsumsi Fast Food, Aktivitas Fisik dan Faktor Keturunan Terhadap Kejadian Obesitas (Studi Kasus pada Siswa SD Negeri 01 Tonjong Kecamatan Tonjong Kebupaten Brebes). Universitas Negeri Semarang, Indonesia

Ramadhaniah, Madarina Julia, Emy Huriyati. 2014. Durasi Tidur, Asupan Energi, dan Aktivitas Fisik dengan Kejadian Obesitas pada Tenaga Kesehatan Puskesmas. Jurnal Gizi Klinik Indonesia, Vol. 11(2): 8596

Ruan, Huijuan, Pengcheng Xun, Wei Cai, $\mathrm{Ka} \mathrm{He}$ and Qingya Tang. 2015. Habitual Sleep Duration and Risk of Childhood Obesity: Systematic Review and Dose- response Metaanalysis of Prospective Cohort Studies. Scientific Report, Vol.5:1-14

Riskesdas 2018. Hasil Utama Riskesdas 2018. Kemeskes Republik Indonesia.

Roemling, C. \& Qaim, M. 2012. Obesity trends and determinants in Indonesia. Appetite, 58(3), pp. 10051013.

Soegih, Rachmad. 2009. Tren Obesitas Dulu, Sekarang, dan yang Akan Datang dalam Obesitas Permasalahan dan Terapi Praktis. Jakarta: Sagung Seto.

Safriana. 2012. Perilaku Memilih Jajanan pada Siswa Sekolah Dasar di SDN Garot Kecamatan Darul Imarah Kabupaten Aceh Besar. Skripsi Diakses di lib.ui.ac.id

Steiner-Asiedu M., Jantuah, J E., Anderson, A K. 2012. The Snacking Habits in Junior High School Students: The Nutritional Implication-A Short Report. Asian J Med Sci, Vol. 4(1): 42-6

Suglia, Shakira F, Seema Kara, and Whitney R. Robinson. 2014. Sleep Duration and Obesity among Adolescents Transitioning to Adulthood: Do Results Differ by Sex? The Journal of Pediatrics, Vol. 165(4): 750-754

Suhardjo. 1989. Sosio Budaya Gizi. Departemen Pendidikan dan Kebudayaan, Direktorat Jendral Pendidikan Tinggi, dan Pusat Antar Universitas Pangan dan Gizi, IPBBogor.

Soekirman. 2000. Ilmu Gizi dan 
Aplikasinya untuk Keluarga dan Masyarakat.Direktorat Jendral Pendidikan Tinggi Departemen Pendidikan Nasional. Bogor

Taheri S, Lin L, Austin D, Young T, Mignot E. 2014. Short Sleep Duration is Associated with Reduce Leptin, Elevated Ghrelin, and Increased Body Mass Index. Plos Medicine; 1(3): 210-217.

Ulya, Novida. 2003. Analisis Deskriptif Pola Jajanan dan Kontribusi Zat Gizi Makanan Jajanan terhadap Konsumsi Sehari dan Status Gizi Anak Kelas IV, V dan VI SD Negeri Cawang 05 Pagi Jakarta Timur. Skripsi. Depok: Gizi Kesehatan asyarakat, FKMUniversitas Indonesia 